\title{
Evaluation of bacterial contaminants and heavy metals in cow and buffalo raw milk sold in Baghdad governorate
}

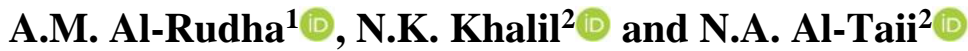 \\ ${ }^{1}$ Department of Public Health, ${ }^{2}$ Zoonosis Research Unit, Veterinary Medicine College, University of Baghdad, Baghdad, Iraq
}

\begin{tabular}{l} 
Article information \\
\hline Article history: \\
Received October 01, 2021 \\
Accepted November 07, 2021 \\
Available online December 16, 2021 \\
\hline Keywords: \\
Bacteria \\
Buffalo \\
Cow \\
Heavy metals \\
Iraq \\
\hline Correspondence: \\
A.M. Al-Rudha \\
asel.mh123@ covm.uobaghdad.edu.iq
\end{tabular}

\begin{abstract}
The purpose of this study was to investigate bacterial contamination and heavy metal concentrations in 80 samples of raw milk (cow: 40 and buffalo: 40) gathered from local markets in Baghdad, Iraq. The culture results were classified into ten categories: E. coli was $100 \%$ in each cows and buffaloes, Enterobacter Spp 23.75\% (25\% cow, 22.5\% buffalo), Pseudomonas Spp 13.75\% (15\% cow,12.5\% buffalo), Klebsiella Spp 15\% (17.5\% cow, $12.5 \%$ buffalo), Staphylococcus aureus $12.5 \%$ (15\% cow, 10\% buffalo), Staph. epidermidis 5\% (for each cow and buffalo), Proteus spp. 10\% (12.5\% cows, $7.5 \%$ buffaloes), E. coli $\mathrm{O} 157$ 15\% (25\% cow, 5\% buffalo), Yersinia enterocolitica 3.75\% (5\% cow, $2.5 \%$ buffalo) and Salmonella $13.75 \%$ (25\% cow 2.5\% buffalo). The averages of heavy metals concentrations in cow milk samples were $0.62 \pm 0.25,0.25 \pm 0.22,0.31 \pm 0.20$ and $21 \pm 2 \mathrm{mg} / \mathrm{kg}$ and in buffalo milk samples were $0.60 \pm 0.3,0.33 \pm 0.15,0.27 \pm 0.11$ and $18 \pm 2.5 \mathrm{mg} / \mathrm{kg}$ for Lead $(\mathrm{Pb})$, Cadmium $(\mathrm{Cd})$, Copper $(\mathrm{Cu})$ and Nickel $(\mathrm{Ni})$ respectively. The high concentrations of pathogenic bacteria and metals found in the milk products is a sign of inadequate hygiene and sanitation during milking and post-milking operations, as well as excessive levels of heavy metal pollution in the environment which will affect meat and milk produced by these animals.
\end{abstract}

DOI: 10.33899/ijvs.2021.131744.1999, (OAuthors, 2021, College of Veterinary Medicine, University of Mosul.

This is an open access article under the CC BY 4.0 license (http://creativecommons.org/licenses/by/4.0/).

\section{Introduction}

Milk and milk products are complete foods for people from birth to old age because they contain all the nutrients necessary for growth and body health protection. Humans have consumed milk for thousands of years (1). Buffalo's and cow's dairy is the essential dairy species all over the world; in many developing countries, milk plays an essential function in satisfying the nutritional demands of humans, it has a rich, complex nutritional value. Buffalo's and cow's milk receive increasing research attention in various countries according to the charming nutrient contents $(1,2)$. The environment, production, storage parameters, microbial and somatic cell counts influence chemical parameters fat and protein content as well as the absence of inhibitory compounds all impact milk and milk products quality. Pseudomonas or Acinetobacter spp. are the common spoilage bacteria, can create heat-stable proteases and lipases, which remain active after pasteurization spoiling milk during long-term storage (3). Milk contains both macroelements such as $\mathrm{Ca}, \mathrm{K}$ and $\mathrm{P}$, also microelements such as $\mathrm{Cu}, \mathrm{Fe}, \mathrm{Zn}$, Se, also may contain heavy metals which come from different sources, including food, water, during manufacturing and packaging, they may reach toxic levels in humans (4). Milk contamination with toxic metals is a health threatening danger to humans, particularly in infants and children because they largely consumed milk (5). Many toxic compounds in animal's milk and meat are of food origin due to contamination of the environment with heavy metals. In food chains and food webs, heavy metals are biotransferred, bioaccumulated, and biomagnified in the animals' bodies and either accumulate or cause injury to them (6). As a non-essential element, lead can be readily 
absorbed through milk, yet it can cause severe diseases like Alzheimer's, kidney, reproductive and endocrine problems and lower children's intelligence quotient (IQ) (7). Cadmium causes antiperistalsis, vomiting, and diarrhea. It may also play a role in developing other health problems, such as high blood pressure, prostate cancer, and even mortality (8). Hepatic Copper II Overload Illness, tissue injury, lung irritation, and hepatic cancer can all be caused by copper overexposure (9).

As a result, the study's goals were to assess the microbiological status of cow and buffalo milk sold in the Iraqi market and to estimate the presence of heavy metals in the milk.

\section{Materials and methods}

\section{Sample collection}

Eighty samples of the raw milk Cow: 40 and buffalo: $40,250 \mathrm{ml}$ for each were collected from markets in Baghdad then were sent in a cool box to the microbiology laboratory in the Department of Public Health, College of Veterinary Medicine, University of Baghdad for isolation and identification of bacterial contaminants and market research and consumer protection center/university of Baghdad to for detection of heavy metals: Lead $(\mathrm{Pb})$, Nickel (Ni), Cadmium (Cd), and Copper (Cu).

\section{Isolation and identification of bacterial contamination}

One $\mathrm{ml}$ of each milk sample was inoculated into $99 \mathrm{ml}$ of peptone broth and incubated at $37^{\circ} \mathrm{C}$ for $24-48$ hours. After incubation, about $0.1 \mathrm{ml}$ of inoculated broth were subcultured on Nutrient agar plates, Blood agar, Eosin methylene blue EMB, MacConky agar, Salmonella Shigella Agar SS Agar, sorbitol-MacConky agar with cefixime tellurite and CIN agar. Biochemical is performed using Epi 20 system $(10,11)$.

\section{Heavy metals analysis}

Determination of heavy metal levels in milk samples was done using Atomic Absorption Spectrophotometer (AAS) according to the dry-ashing method that was described by (12) which is done by three steps: [1] Preparation the sample which include: drying stage, incineration stage, winnowing stage and cleaning stage. [2] preparation of standard solutions $0.01,0.02$ and 0.04 and measure them to compare with samples measures. [3] Inoculation of samples in spectrophotometer and taking measures.

One hundred $\mathrm{ml}$ of each milk sample were kept in the oven at $80^{\circ} \mathrm{C}$ for $48 \mathrm{~h}$ or until dried. The heavy metals analysis was performed by adding con. $\mathrm{HNO}_{3}$ in to the dried milk powder, $0.5 \mathrm{~g}$ of dried milk with $5 \mathrm{ml}$ of con. $\mathrm{HNO}_{3}$ were taken in to the digestion flask then heated at $80-90^{\circ} \mathrm{C}$ for $10 \mathrm{~min}$ by placing on hot plat for digestion then raised to $100^{\circ} \mathrm{C}$, more acid was added up to $3-5 \mathrm{ml}$ until clear solution was obtained. The samples were cooled at room temperature and filtered through filter paper and the sample volume was completed with deionized water to $25 \mathrm{ml}$ in volumetric flask $(12,13)$. Statistical analysis of samples was done using SAS 2010.

\section{Results}

The result revealed from 80 milk samples submitted from buffaloes 40, cows 40. The culture results were classified into ten categories: E. coli was $100 \%$ in each cows and buffaloes, Enterobacter Spp 23.75\% :25\% cow, $22.5 \%$ buffalo, Pseudomonas Spp $13.75 \%: 15 \%$ cow, $12.5 \%$ buffalo, Klebsiella Spp 15\%:17.5\% cow, $12.5 \%$ buffalo, Staphylococcus aureus 12.5\% :15\% cow, 10\% buffalo, Staph. epidermidis 5\% for each cow and buffalo, Proteus spp. 10\%:12.5\% cows, $7.5 \%$ buffaloes, E. coli $015715 \%$ $: 25 \%$ cow, $5 \%$ buffalo, Yersinia enterocolitica $3.75 \%: 5 \%$ cow, $2.5 \%$ buffalo and Salmonella $13.75 \%$ : $25 \%$ cow $2.5 \%$ buffalo as shown in table 1 . The mean of $\mathrm{Pb}, \mathrm{Cd}, \mathrm{Cu}$ and $\mathrm{Ni}$ concentrations in examined milk samples were $0.62 \pm 0.25$, $0.25 \pm 0.22,0.31 \pm 0.20$ and $21 \pm 2 \mathrm{mg} / \mathrm{kg}$ in cow milk samples and $0.60 \pm 0.3,0.33 \pm 0.15,0.27 \pm 0.11$ and $18 \pm 2.5 \mathrm{mg} / \mathrm{kg}$ in buffalo milk samples respectively (Table 2). There are no statistically significant differences between results of cow and buffalo milk samples in both bacterial and heavy metals contaminants at $\mathrm{P}<0.05$.

Table 1: percentage of isolated bacteria in cow and Buffalo milk samples

\begin{tabular}{lccc}
\hline Isolated bacteria & No. of isolate (cow) & No. of isolate (Buffalo) & Total No. of isolates \\
\hline E. coli & $40(100 \%)$ & $40(100 \%)$ & $80(100 \%)$ \\
Enterobacter Spp & $10(25 \%)$ & $9(22.5 \%)$ & $19(23.75 \%)$ \\
Pseudomonas Spp & $6(15 \%)$ & $5(12.5 \%)$ & $11(13.75 \%)$ \\
Klebsiella Spp & $7(17.5 \%)$ & $5(12.5 \%)$ & $12(15 \%)$ \\
Staph aureus & $6(15 \%)$ & $4(10 \%)$ & $10(12.5 \%)$ \\
Staph epidermidis & $2(5 \%)$ & $2(5 \%)$ & $4(5 \%)$ \\
Proteus spp. & $5(12.5 \%)$ & $3(7.5 \%)$ & $8(10 \%)$ \\
E. coli O157 & $10(25 \%)$ & $2(5 \%)$ & $12(15 \%)$ \\
Yersinia enterocolitica & $2(5 \%)$ & $1(2.5 \%)$ & $3(3.75 \%)$ \\
Salmonella & $10(25 \%)$ & $1(2.5 \%)$ & $11(13.75 \%)$ \\
\hline
\end{tabular}


Table 2: percentage of heavy metals $\mathrm{mg} / \mathrm{kg}$ in cow and Buffalo milk samples

\begin{tabular}{lcc}
\hline \multirow{2}{*}{ Heavy Metal } & \multicolumn{2}{c}{ mean \pm SE } \\
\cline { 2 - 3 } & Cow milk & Buffalo milk \\
\hline $\mathrm{Pb}$ & $0.62 \pm 0.25$ & $0.60 \pm 0.3$ \\
$\mathrm{Cd}$ & $0.25 \pm 0.22$ & $0.33 \pm 0.15$ \\
$\mathrm{Cu}$ & $0.31 \pm 0.20$ & $0.27 \pm 0.11$ \\
$\mathrm{Ni}$ & $21 \pm 2$ & $18 \pm 2.5$ \\
\hline
\end{tabular}

\section{Discussion}

Escherichia coli spp. was found in all of our samples at $100 \%$, while E. coli O157 was found in just $15 \%$ of them (25\% cow and $5 \%$ Buffalo). The present findings are in agreement with those of (14), who discovered that $E$. coli was the most common bacterial isolate $(49.8 \%)$ in his study on bacterial pathogens causing subclinical mastitis in three bovine dairy herds in three governorates in north upper Egypt.

The present study showed milk samples contaminated with Staphylococcus aureus (15\% cow, $10 \%$ buffalo) and with Staphylococcus epidermidis 5\% (for each cow and buffalo), this is lower than (15) who found that the most agents isolated from milk samples at four dairy farms in São Paulo State, Brazil, were Staphylococcus epidermidis and Staph. aureus 17\% and 15\% respectively, and also lower than (14) who recorded $44.9 \%$ S. aureus from three bovine herds in Egypt.

Bhutia et al. (16) recorded 28.7\% Staphylococcus spp. from clinical mastitis in buffaloes, India from 2007 to 2016, due to poor hygienic practices for milking lead to high infection with Staph. spp.

Our finding showed that Pseudomonas Spp was 15\% cow, $12.5 \%$ buffalo, Klebsiella spp $17.5 \%$ cow, $12.5 \%$ buffalo and Enterobacter spp. 25\% cow, 22.5\% buffalo, these results were higher than (15) who found Pseudomonas aeruginosa 9.5\%; Klebsiella rhinoscleromatis $0.5 \%, \quad$ Klebsiella ozaenae $0.5 \%$, Enterobacter cloacae $0.5 \%$ during their study on bacteria causing subclinical mastitis of Buffalo in Brazil, but our findings were lower than the result of (17) who recorded Klebsiella spp 21.4\% in Damascus and its countryside. Our result of Salmonella 25\% cow and 2.5\% buffalo was higher than (18) who found 19\% of Salmonella were isolated from plastic container milk.

High infection rates with pathogens are caused by smallholders' use of their hands and traditional equipment for milking practices, which raises the risk of bacterial transmission into milk and dairy products (19). Milk contamination with bacteria may also result from the unhygienic manner of animals, contamination of milk with feces and infected animal wastes, transmission of pathogenic agents from the infected staff and due to uneffective cooling of raw milk samples at temperatures below $4^{\circ} \mathrm{C}$ which facilitates the survival and proliferation of bacteria (20).

Our results showed that the mean of $\mathrm{Pb} 0.62 \pm 0.25$, $0.60 \pm 0.3, \quad \mathrm{Cd} \quad 0.25 \pm 0.22, \quad 0.33 \pm 0.15, \quad \mathrm{Cu} \quad 0.31 \pm 0.20$, $0.27 \pm 0.11$ and $\mathrm{Ni} 21 \pm 2,18 \pm 2.5 \mathrm{mg} / \mathrm{kg}$ for cow and buffalo milk samples respectively, these findings were higher than permissible limits determined by $(21,22)$ which are: 0.05 , $0.026,0.10$ and $0.10 \mathrm{mg} / \mathrm{kg}$ for $\mathrm{Pb}, \mathrm{Cd}, \mathrm{Cu}$ and $\mathrm{Ni}$ respectively.

These results were higher than (23) on his study on 30 milk samples of Buffalo and cow collected from dairy shops and groceries at El-Behera governorate/ Egypt, he recorded $\mathrm{Cd}$ and $\mathrm{Pb}$ levels in cow milk were $0.0978 \pm 0.01948,0.3425 \pm 0.03980 \mathrm{ppm}$ and in Buffalo milk were $0.1892 \pm 0.01239,0.4854 \pm 0.05043 \mathrm{ppm}$ respectively, also our findings were higher than (13) who studied the concentrations of heavy metals in milk samples collected from southern China, levels of $\mathrm{Pb}, \mathrm{Cd}, \mathrm{Cu}$, and $\mathrm{Ni}$ were $0.0062 \pm 0.0022, \quad 0.0019 \pm 0.0011, \quad 0.0439 \pm 0.015 \quad$ and $0.0552 \pm 0.0813 \mathrm{mg} / \mathrm{kg}$ respectively in sterilized milk samples, $0.0089 \pm 0.0048, \quad 0.0034 \pm 0.0008, \quad 0.0621 \pm 0.0239$ and $0.0403 \pm 0.0290 \mathrm{mg} / \mathrm{kg}$ in Fermented milk, $0.0068 \pm 0.0022, \quad 0.0041 \pm 0.0047, \quad 0.0499 \pm 0.0106 \quad$ and $0.0423 \pm 0.0122 \mathrm{mg} / \mathrm{kg}$ in Modified milk.

In this study, the results were also higher than those of (24) who studied the concentration of heavy metals and the risk associated with the consumption of raw fresh milk from Buffalo, cow, sheep, and goats in Aswan Province/Egypt and 16 samples of Kareish cheese, Domiati cheese, Mish, and Samna milk products in Aswan Province/Egypt, he recorded that heavy metals arranged from $\mathrm{Pb}$ 0.159- 0.733, $\mathrm{Cd}$ 0.013- 0.060, $\mathrm{Cu}$ 0.041- 0.079 $\mathrm{mg} / \mathrm{kg}$ in Buffalo, $\mathrm{Pb} 0.209-0.430, \mathrm{Cd}$ 0.027- 0.036, $\mathrm{Cu}$ 0.111-0.133 mg/kg in cow, $\mathrm{Pb} 0.143-0.254, \mathrm{Cd} 000-0.030$, $\mathrm{Cu} 0.254-0.336 \mathrm{mg} / \mathrm{kg}$ in goat and $\mathrm{Pb}$ 0.147- 0.737, $\mathrm{Cd}$ 0.004- 0.029, Cu 0.148- $0.315 \mathrm{mg} / \mathrm{kg}$ in sheep.

Our findings are in agreement with those of (25) who measure the levels of heavy metals $\mathrm{Fe}, \mathrm{Cu}, \mathrm{Pb}, \mathrm{Ni}$, and $\mathrm{Cd}$ in 90 samples of cow and buffalo milk and dairy products (cheese and cream) collected from three regions in Basrah such as Basrah center, Abu Al-Khaseeb, and Al-Zubair, their investigations showed that the levels of $\mathrm{Fe}$, were $2.90 \pm 0.01,6.32 \pm 0.02$, and $4.39 \pm 0.02$ respectively, for $\mathrm{Cu}$ were $0.37 \pm 0.01,0.35 \pm 0.03$, and $0.03 \pm 0.01$, and for $\mathrm{Pb}$ $0.00 \pm 0.00,0.05 \pm 0.02$ and $0.29 \pm 0.01$ respectively for the

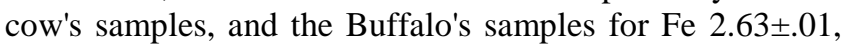
$1.72 \pm .02$, and $2.10 \pm .02$, for $\mathrm{Cu} 1.85 \pm 0.01,0.43 \pm 0.01$ and $54 \pm 0.01$ and $\mathrm{Pb} 0.00 \pm 0.00,0.35 \pm 0.01$ and $0.67 \pm 0.01$ respectively, while the levels of $\mathrm{Ni}$ and $\mathrm{Cd}$ were not detected in all samples in their study.

The sources of contamination of raw milk with heavy metals are numerous, including the air (through inhalation of animals), water (through watering cans and utensils used for drinking water), fodder (as a result of contamination of the feed ingredients through the use of chemical materials 
by farmers such as fertilizers, insecticides, fungicides, sterilizers and mineral additives to the diet), also through the bad habits of the animal, especially the cows, like licking the poles, steel bars, metal troughs, as well as through solid metal and plastic waste such as lead tables that left in the field (12).

The concentration of heavy metals in milk is not affected by heat treatments during the process of pasteurization, condensation, and drying that is carried out on raw milk from livestock during the production process and may even increase the concentration of these elements as a result of milk contamination through tools, metal machines, covers, bags and metal cans used in manufacturing, packaging of powdered, pasteurized liquid and condensed milk products, the presence of heavy elements is one of the most important health pollution problems for human food in the world recent years (22).

\section{Conclusion}

The high concentrations of pathogenic bacteria and metals found in the milk products is a sign of inadequate hygiene and sanitation during milking and post-milking operations, as well as excessive levels of heavy metal pollution in the environment which will affect meat and milk produced by these animals.

\section{Acknowledgments}

Appreciation goes to Zoonotic Diseases Researches Unit, Veterinary Medicine College, University of Baghdad, Iraq

\section{Conflict of interest}

No conflict of interest was reported with this study.

\section{References}

1. Evershed R, Payne S, Sherratt A, Copley M, Coolidge J, Urem-Kotsu $D$, Kotsakis $K$, Ozdoğan $M$, Ozdoğan A, Nieuwenhuyse $O$, Akkermans P, Bailey M. Earliest date for milk use in the Near East and southeastern Europe linked to cattle herding. Nature. 2008;455(7212):528-31. DOI: $10.1038 /$ nature07180

2. Amarjit $\mathrm{S}$ and Toshihiko N. Role of buffalo in the socioeconomic development of rural Asia: Current status and future prospectus. Anim Sci J. 2003;74(5):443-445. DOI: 10.1046/j.1344-3941.2003.00138.x

3. Vincenzina F, Daniele C, Francesca F, Antonio F, Logrieco G, Jan K, Christina B, Charles M. Microbial quality and safety of milk and milk products in the $21^{\text {st }}$ century. Food Sci Food Saf. 2020;19(4):20132049. DOI: $10.1111 / 1541-4337.12568$

4. Qin L, Wang X, Li W, Tong X, Tong W. The minerals and heavy metals in cow's milk from China and Japan. J Hlth Sci. 2009;55(2):300-305 DOI: 10.1248/jhs.55.300

5. Al-Khafaf A, Ismail H, Al-Saidya A. Histopathological effects of experimental exposure to lead on nervous system in albino female rats. Iraqi J Vet Sci. 2021;35(1):45-48. DOI: 10.33899/ijvs.2019.126248.1273
6. Al-Naemi H, Al-Sanjary R, Faraj R, Saadi A. Detection of lead, chromium and cobalt in meats of cattle and buffalo from retails of Mosul city. Iraqi J Vet Sci. 2020;34(2):447-451. DOI: 10.33899/ijvs.2019.126069.1224

7. Ahmad N, Rahimb M, Haris M. Toxicological impact assessment of heavy metals in human blood and milk samples collected in district Shangla. Pakistan Sci Int. 2014;26(1):223-226. [available at]

8. Giuseppe G, Sinicropi MS, Graziantonio L, Catalano A. The Effects of cadmium toxicity. Inter $\mathrm{J}$ Environ Res Public Hlth. 2020;17(11):3782. DOI: 10.3390/ijerph17113782

9. Bushra I, Saatea A, Samina S, Riaz K. Assessment of toxic metals in dairy milk and animal feed in Peshawar, Pakistan. British Biotech J. 2014;4(8):883-893. DOI: 10.9734/BBJ/2014/9939

10. Al-Rudha A, Al-Rubaie E, Khalil N. Distribution of E.coli $\mathrm{O} 157: \mathrm{H} 7$ in fecal and urine samples of cattle. The Iraqi $\mathrm{J}$ Vet Med. 2016;40(1):79-82. DOI: $10.13140 / R G .2 .2 .12767 .30884$

11. Putra A, Effendi M, Koesdarto S, Suwarno S, Tyasningsih W, Estoepangestie A. Detection of the extended spectrum $\beta$-lactamase produced by Escherichia coli from dairy cows by using the Vitek-2 method in Tulungagung regency, Indonesia. Iraqi $\mathbf{J}$ Vet Sci. 2020;34(1):203-207. DOI: 10.33899/ijvs.2019.125707.1134

12. Al-Shdidi A. Study of pollution levels of heavy metals residues in the locally produced cheese and emulsifying salts. The Iraqi J Vet Med. 2010;34(2):188-193. DOI: 10.30539/iraqijvm.v34i2.650

13. Meijuan Y, Yonglin L, Varenyam A, Qing-Long F, Lanhai L. Health risk assessment of al and heavy metals in milk products for different age groups in China. Pol J Environ Stud. 2015;24(6):2707-2714. DOI: 10.15244/pjoes/58964

14. Abed A, Menshawy A, Zeinhom M, Hossain D, Khalifa E, Wareth G, Awad M. Subclinical mastitis in selected bovine dairy herds in north upper Egypt: Assessment of prevalence, causative bacterial pathogens, antimicrobial resistance and virulence-associated genes. Microorganisms. 2021;9(6):1175. DOI: 10.3390/9061175

15. Vásquez-García A, Silva T, Almeida-Queiroz S, Godoy S, Fernandes A, Sousa R, Franzolin R. Species identification and antimicrobial profile of bacteria causing subclinical mastitis in buffalo. Pesquisa Vet Brasil. 2017;37(5):447-452. DOI: 10.1590/S0100-736017000500004

16. Bhutia P, Bansal B, Gupta D, Singh R, Uppal S. Bacterial isolation of milk samples submitted from clinical mastitis buffaloes during 2007 to 2016. Trop Anim Hlth Prod. 2019;51:1551-1557. DOI: 10.1007/-w

17. Soulieman N, Al-Mariri A, Al-Atrash F. Detection of Shigella in raw bovine milk by polymerase chain reaction. Iraqi $\mathrm{J}$ Vet Sci. 2020;34(1):9-16. DOI: 10.33899/ijvs.2019.125758.1146

18. Fesseha $\mathrm{H}$, Aliye $\mathrm{S}$, Kifle $\mathrm{T}$, Mathewos M. Isolation and multiple drug resistance patterns of salmonella isolates from selected dairy farms in Hawassa town, Ethiopia. J Vet Sci Med. 2020;8(1):7. [available at]

19. Abunna F, Worku H, Gizaw F. Assessment of postharvest handling practices, quality and safety of milk and antimicrobial susceptibility profiles of Escherichia coli O157:H7 isolated from milk in and around Asella town, Oromia, Ethiopia. Ann Public Hlth Res. 2018;5(1):1072. [available at]

20. Hickey C, Sheehan J, Wilkinson M, Auty M. Growth and location of bacterial colonies within dairy foods using microscopy techniques: A review. Front Microbiol. 2015;6:99. DOI: 10.3389/fmicb.2015.00099

21. Al-Dabbagh AS. Estimation of lead and copper levels in milk. J AlRafidain Sci. 2013;24(2):24-35. DOI: 10.33899/ris.2013.71019

22. Birghila S, Dobrinas S, Stanciu, G, Soceanu, A. Determination of major and minor elements in milk through ICP-AES. Environ Engin Manage J. 2008;7(6):805-808. [available at]

23. El-Ansary M. and El-Leboudy A. Levels of cadmium and lead in raw cow and buffalo's milk samples collected from local markets of ElBehera governorate. Alexandaria J Vet Sci. 2015;47:129-133.DOI: 10.5455/ajvs. 199860

24. Khalil O. Risk assessment of certain heavy metals and trace elements in milk and milk products consumed in Aswan province. J Food Dairy Sci. 2018;9(8):289-296. DOI: 10.21608/JFDS.2018.36018

25. Al-Garory N, Al-Kaabi W. Determination of some heavy metals concentration in some dairy products from three different regions of Basrah, Iraq. Basrah J Agri Sci. 2020;33(2):1-13. [available at] 


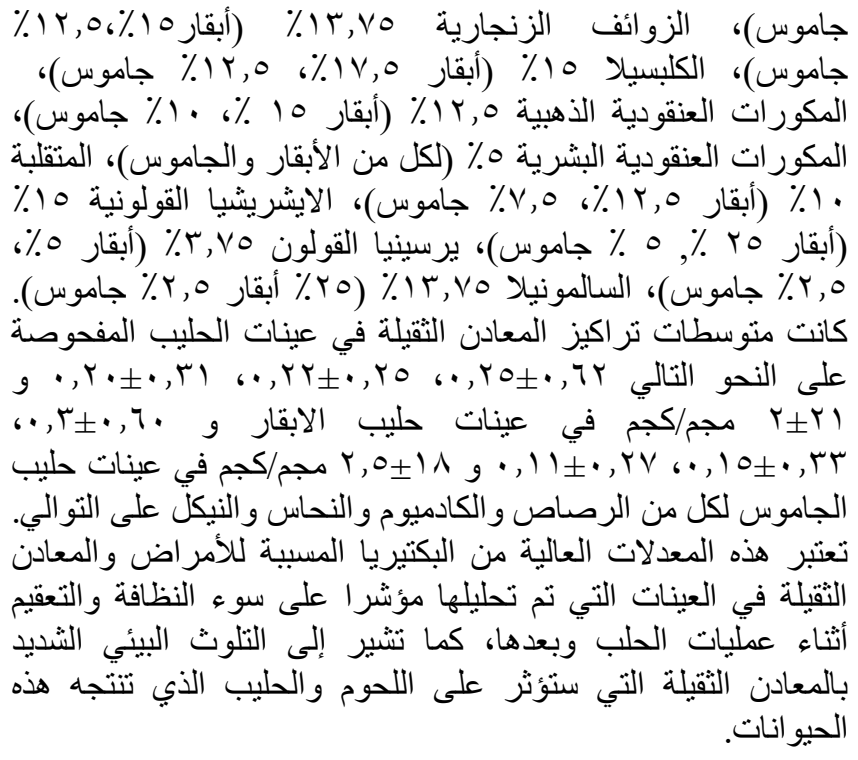

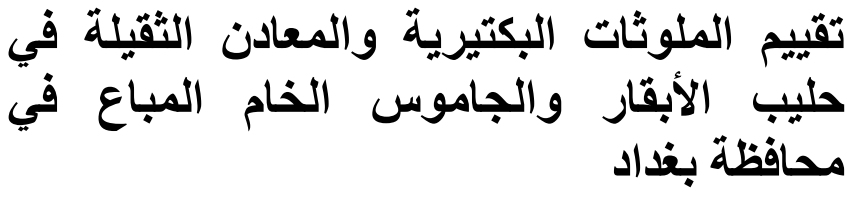

اسيل محمد عبد الرضا'، نهى خلف خليل و نور عبد الحميد الطائي

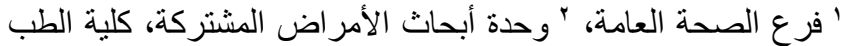
البيطري، جامعة بغداد، بغداد، العر اق اق التان

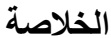

تم تحديد هذه الدراسة لتقييم الملوثات البكتيرية وتركيز المعادن

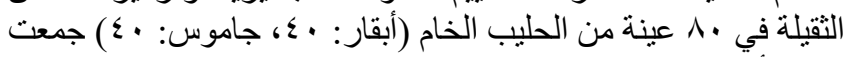

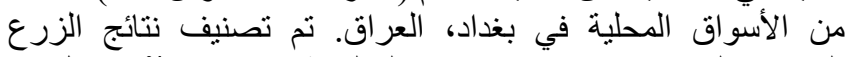

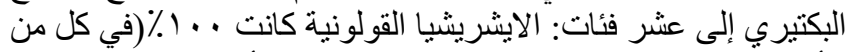

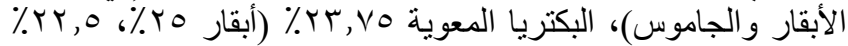

